\section{Spreadin' the news}

\section{By Kai-Jye Lou, Staff Writer}

One of the most active areas of strategic repositioning in the translational space in 2011 occurred at the level of public-private partnerships established to expand corporate research portfolios and strengthen institutional research programs.

To gain an accurate picture of what really went on, SciBX performed a comprehensive analysis of public-private partnership (PPP) activity worldwide and contrasted it to early stage venture investing during the same period.

Highlights include the emergence of New York as a translational hub, the impact of nongovernmental funding on infectious disease research compared with the more muted VC support of this area, and the high interest of foreign companies in funding research in China.

\section{Location, location}

Globally, the U.S. continued to dominate the PPP landscape, with about half of the deals involving a U.S. institution or a U.S. company (see Figure 1, "Breakdown of global public-private partnerhsips by

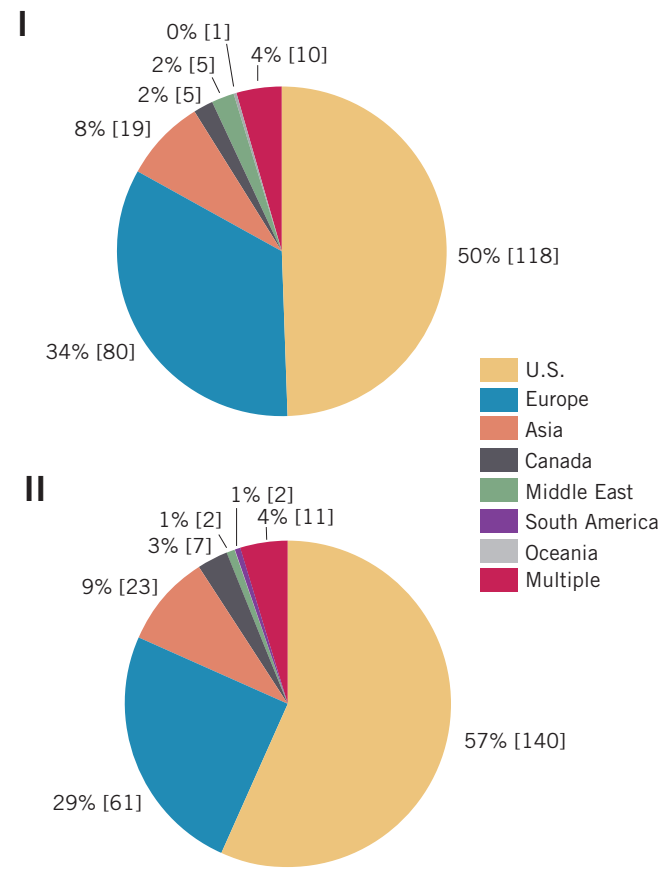

Figure 1. Breakdown of global public-private partnerships by companies (I) and institutions (II). Percentages are out of total number of public-private partnerships worldwide; bracketed values are actual number.
Table 1. Leaders in the number of public-private partnerships. U.S. institutes were involved in over half of the reported public-private partnerships (PPPs) in 2011, with such institutes taking four of the five top spots in terms of the number of deals done. Although U.S. companies were involved in about half of the reported PPPs in 2011, France's Sanofi was by far the most active single company. Excludes deals that only involve IP transfer.

Source: BioCentury Archives

\begin{tabular}{lc}
\hline Institute & Number of PPPs \\
\hline University of California (UCSF/UCSD/UCD/UCLA) & 10 \\
\hline NIH (includes NCI/NHGRI/NIAID) & 7 \\
\hline Columbia University & 6 \\
\hline Harvard University & 6 \\
\hline BGI (formerly the Beijing Genomics Institute) & 5 \\
\hline Company & 12 \\
\hline Sanofi (Euronext:SAN; NYSE:SNY) & 9 \\
\hline AstraZeneca plc (LSE:AZN; NYSE:AZN) & 9 \\
\hline Pfizer Inc. (NYSE:PFE) & 9 \\
\hline Roche (SIX:ROG; OTCQX:RHHBY) & 6 \\
\hline Johnson \& Johnson (NYSE:JNJ) & 6 \\
\hline GlaxoSmithKline plc (LSE:GSK; NYSE:GSK) & \\
\hline
\end{tabular}

companies and institutions" and Table 1, "Leaders in the number of public-private partnerships"). A more detailed look at the data, however, provides several interesting regional insights (see Figure 2 , "Regional breakdown of companies and institutions involved in public-private partnerships in the top six U.S. states, top five European countries and top five Asian countries").

During 2011, New York's desire to become a bona fide hub for biopharma was bolstered by the level of PPP activity at the state's research institutes and universities. Indeed, universities in the state were involved in the three PPPs with the highest disclosed values last year (see Table 2, “Top five public-private partnerships by value”).

The state also is being buoyed by the recent appointments of Marc Tessier-Lavigne as president of The Rockefeller University and Laurie Glimcher as dean of Weill Cornell Medical College. ${ }^{1}$

In addition to boasting the biggest deals, New York institutions also had the most PPPs in 2011 with 32 disclosed collaborations. The state edged out the 26 deals by universities in California (see Figure 2.I).

On the corporate side, California biopharma companies were the most active in the U.S. and entered into 31 PPPs last year.

In Europe, the U.K. was the clear leader in PPP activity in 2011. U.K. institutes announced 24 PPPs, whereas U.K. companies entered into 34 (see Figure 2.II).

Overall, the single most active company was Sanofi, which did 12 PPPs last year. This includes two R\&D partnerships with the University of California, San Francisco ${ }^{2}$ and a three-year research collaboration with Columbia University to investigate the use of osteocalcin as a diabetes therapeutic. ${ }^{3}$

In Asia, Japanese companies and Chinese institutes had the most PPP activity last year (see Figure 2.III). Companies in Japan partnered with an even mix of institutes within the country's own borders and in 


\section{ANALYSIS}

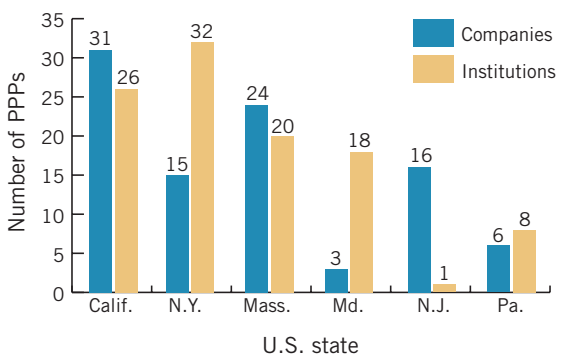

II

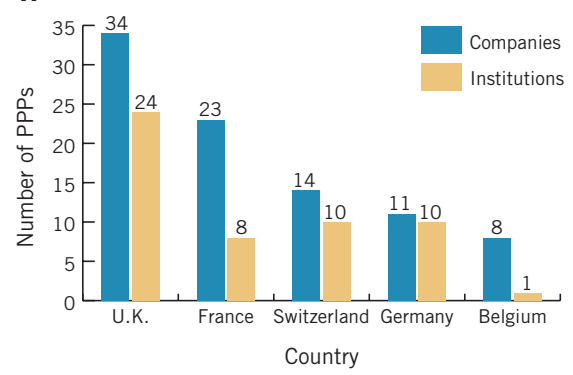

III

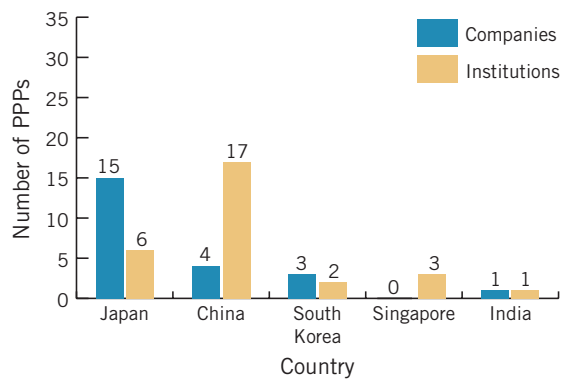

Figure 2. Regional breakdown of companies and institutions involved in public-private partnerships in the top six U.S. states (I), top five European countries (II) and top five Asian countries (III). Values refer to the actual number of companies or institutions.

Table 2. Top five public-private partnerships by value. Three of the five largest public-private partnerships (PPPs) in 2011 are valued at $\$ 100$ million or more. Listed PPPs do not include award and grant programs established by government institutes. Only 58 of the 247 PPPs reported in 2011 had disclosed dollar amounts. Excludes deals that only involved IP transfer.

Source: BioCentury Archives

\begin{tabular}{|c|c|c|c|}
\hline Companies & Institutes & Business area & $\begin{array}{l}\text { Disclosed } \\
\text { value (\$M) }\end{array}$ \\
\hline $\begin{array}{l}\text { Illumina Inc. (NASDAQ:ILMN)/ } \\
\text { Roche (SIX:ROG; OTCQX:RHHBY) }\end{array}$ & New York Genome Center/11 U.S. institutes & Genomics & $\$ 125^{\mathrm{A}}$ \\
\hline Gilead Sciences Inc. (NASDAQ:GILD) & Yale University & Cancer & $\$ 100$ \\
\hline Pfizer Inc. (NYSE:PFE) & $\begin{array}{l}\text { The Rockefeller University/New York University Langone Medical } \\
\text { Center/Mount Sinai Medical Center/Columbia University } \\
\text { Medical Center/Albert Einstein College of Medicine of Yeshiva } \\
\text { University/Weill Cornell Medical College }\end{array}$ & Pharmaceuticals & $\$ 100$ \\
\hline Advance BioChina & Institut Pasteur of Shanghai & Pharmaceuticals & $\$ 47.5-\$ 95^{\mathrm{B}}$ \\
\hline Vertex Pharmaceuticals Inc. (NASDAQ:VRTX) & Cystic Fibrosis Foundation & Pulmonary disease & $\$ 75$ \\
\hline
\end{tabular}

the U.S. In contrast, Chinese institutes found most of their partners in the U.S. Among these is Huya Bioscience International LLC, which has operations in both Shanghai and San Diego.

Huya is focused on establishing collaborations to develop and commercialize China-sourced therapeutic candidates outside of China.

\section{Follow the money}

The specific areas of PPPs mirrored early stage financing activity in 2011, with cancer taking the top spot in both cases. The notable exception was infectious diseases, which took the second spot in terms of the number of PPPs in 2011 but placed fifth in terms of seed and series A financing activity (see Figure 3, "Breakdown of therapeutic areas covered by seed or series A financing and public-private partnerships in 2011").

Not surprisingly, the largest series A round in 2011 went to cancer and infectious diseases company Ascletis Inc., which pulled in $\$ 50$ million in the first tranche of a planned $\$ 100$ million series $\mathrm{A}$ round led by Hangzhou Binjiang Investment Holding Co. Ltd. The biotech was founded in April 2011 and has operations in Chapel Hill
Figure 3. Breakdown of therapeutic areas covered by seed or series A financing (I) and public-private partnerships in 2011 (II). For (I), percentages are out of total financing events across all therapeutic areas; bracketed values

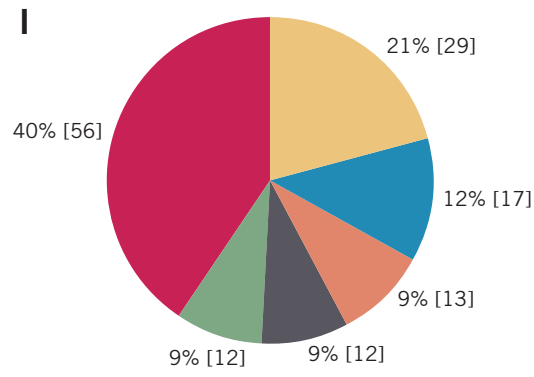

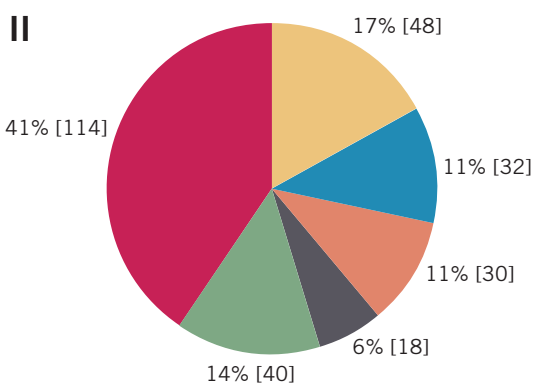

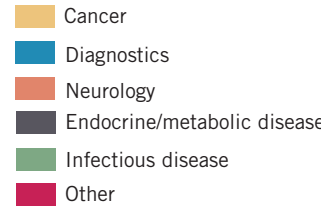

are the actual number of companies that received financing for a given therapeutic area. For (II), percentages are out of the total number of public-private partnerships worldwide; bracketed values are actual numbers. 


\section{ANALYSIS}

Table 3. Top five venture financing rounds for companies founded in 2011. The five largest series A rounds for companies founded in 2011 went to those with U.S. operations. Among the 31 companies founded in 2011 that disclosed they received venture financing that year, there were 21 U.S. companies, 5 based in the U.K., 2 in Canada, 2 in Austria and 1 in Singapore.

Source: BCIQ: BioCentury Online Intelligence

\begin{tabular}{lccc}
\hline $\begin{array}{l}\text { Companies founded } \\
\text { in 2011 }\end{array}$ & Business area & $\begin{array}{c}\text { Financing } \\
\text { type }\end{array}$ & $\begin{array}{c}\text { Amount } \\
\text { raised (\$M) }\end{array}$ \\
\hline Ascletis Inc. ${ }^{\mathrm{A}}$ & $\begin{array}{c}\text { Cancer; } \\
\text { infectious disease }\end{array}$ & $\begin{array}{c}\text { Venture } \\
(\text { series A) }\end{array}$ & $\$ 50^{\mathrm{B}}$ \\
\hline Cleave Biosciences Inc. & Cancer & $\begin{array}{c}\text { Venture } \\
\text { (series A) }\end{array}$ & $\$ 42$ \\
\hline Blueprint Medicines & Cancer & $\begin{array}{c}\text { Venture } \\
\text { (series A) }\end{array}$ & $\$ 40$ \\
\hline Sage Therapeutics Inc. & Neurology & $\begin{array}{c}\text { Venture } \\
(\text { series A) }\end{array}$ & $\$ 35$ \\
\hline Lotus Tissue Repair Inc. & Dermatology & $\begin{array}{c}\text { Venture } \\
(\text { series A) }\end{array}$ & $\$ 26$ \\
\hline
\end{tabular}

${ }^{\mathrm{A} C}$ Company has operations in both U.S. and China. ${ }^{\mathrm{B} A m o u n t}$ raised is first half of a $\$ 100$ million series $A$ round.

and Hangzhou (see Table 3, “Top five venture financing rounds for companies founded in 2011").

Within the cancer space, an overarching theme was targeted therapies. Indeed, the specific oncology indications were all over the map, but at least 20 of 48 PPPs were aimed towards developing targeted molecules.

One reason for the disconnect between partnering activity and startup money in infectious diseases is due to the availability of funding from sources such as nongovernmental organizations (NGOs) that are focused on eradicating tropical diseases and tuberculosis. Of the 40 reported PPPs covering infectious diseases, at least nine covered mosquito-borne illnesses such as malaria and dengue and another six focused on TB. At least 1 NGO was involved in 11 of these 15 PPPs.

Other top areas for PPPs last year were diagnostics, endocrine and metabolic diseases and neurology.

Lou, K.-J. SciBX 5(3); doi:10.1038/scibx.2012.59

Published online Jan. 19, 2012

\section{REFERENCES}

1. Kotz, J. SciBX 5(2); doi:10.1038/scibx.2012.31

2. Osherovich, L. SciBX 4(4); doi:10.1038/scibx.2011.92

3. Cain, C. SciBX 4(15); doi:10.1038/scibx.2011.417

\section{COMPANIES AND INSTITUTIONS MENTIONED}

Ascletis Inc., Chapel Hill, N.C.

Columbia University, New York, N.Y.

Hangzhou Binjiang Investment Holding Co. Ltd., Hangzhou, China

Huya Bioscience International LLC, San Diego, Calif.

The Rockefeller University, New York, N.Y.

Sanofi (Euronext:SAN; NYSE:SNY), Paris, France

University of California, San Francisco, Calif.

Weill Cornell Medical College, New York, N.Y. 